\title{
Leptin and insulin in the seminal plasma of zebu bulls in peripuberty ${ }^{1}$
}

\section{Fernando Andrade Souza ${ }^{2}$, Jorge André Matias Martins ${ }^{3}$, Vicente Ribeiro do Vale Filho², Venício José de Andrade ${ }^{2}$, Marcos Brandão Dias Ferreira ${ }^{4}$, Lucas Luz Emerick ${ }^{2}$, Pablo Fabricio Bruno Pinto ${ }^{2}$, Ticiano Guimarães Leite ${ }^{2}$}

\author{
${ }^{1}$ Research sponsored by FAPEMIG and CNPq \\ 2 Escola de Veterinária/UFMG. \\ ${ }^{3}$ Universidade Federal do Ceará/UFC. \\ ${ }^{4}$ EPAMIG.
}

\begin{abstract}
In order to determine the profile of leptin and insulin values in seminal plasma and their correlations with sperm patterns during the peripuberty, a total of 16 crossbred Gyr dairy bulls were monitored from 60 days before to 60 days after puberty, separated into two groups, early and regular, according to the onset of puberty. Hormone values were determined by radioimmunoassay after gel filtration in fast performance liquid chromatography and semen patterns, according to the Brazilian College of Animal Reproduction. Insulin concentrations in seminal plasma did not differ between groups, nor between the ages, with the pooling of the data showing average of $35.15 \pm 16.93,36.60 \pm 26.21,26.82 \pm 09.81$, and $43.56 \pm 31.7132 .24 \pm 16.71 \mathrm{U} / \mathrm{mL}$ for the pubertal period of $-60,-30,0,+30$ and +60 days, respectively. These values were not correlated with sperm parameters, but differed in the group of animals with the highest percentage of major defects $(31.08 \pm 18.58 \mathrm{U} / \mathrm{mL})$ compared with those with lower percentage of these sperm defects $(40.01 \pm 25.37 \mathrm{U} / \mathrm{mL})$. Leptin was not correlated with sperm parameters and did not differ between groups or stage of sexual development, with concentrations of $23.10 \pm 10.43,24.35 \pm 9.42,22.41 \pm 9.90,23.76 \pm 9.69$ and $24.99 \pm 11.42 \mathrm{ng} / \mathrm{mL}$ for the periods of puberty aforementioned, respectively, after being grouped. These results demonstrated the binding of insulin to the structural quality of the sperm cell, and this hormone is indicated in andrologycal evaluation of future breeding soundness.
\end{abstract}

Key Words: Gyr dairy bulls, puberty, sperm defect

\section{Introduction}

Seminal plasma is a complex mixture of secretions originated in the testes, epididymis and accessory sex glands (Manjunath et al., 1993), serving as a vehicle and containing factors that influence the fertilization capability of the ejaculated spermatozoids (Calvete et al., 1996). Among these factors, leptin stands out and may influence the sperm cells positive (Andò \& Aquila, 2005) and negatively (Glander et al., 2002).

In recent years, it has been shown that this hormone can act at different levels on the hypothalamic-pituitary-testicular axis, and the sperm cell itself (Nikbakh et al., 2010), and can influence the mechanisms involved in the development of motility sperm and the acrosome reaction (Jorsaraei et al., 2008). Another hormone that also plays a central role in the regulation of gonadal function and quality of seminal plasma is insulin. According to Nakayama et al. (1999), insulin promotes the differentiation of spermatogonia into primary spermatocytes by binding to the IGF-I receptors in the gonadal tissue.
In addition, insulin has the plasmatic membrane of the sperm and its acrosome as cytological targets (Silvestroni et al., 1992), which may affect fertilization by influencing the motility, the acrossomal status or the metabolism of the sperm cell (Shrivastav et al., 1989; Silvestroni et al., 1992).

Thus, the objective of this study was to determine the profile of leptin and insulin values in seminal plasma and their correlations with sperm quality parameters and sexual development achieved during the peripuberty of Gyr dairy bulls.

\section{Material and Methods}

This study was conducted at the Getulio Vargas Experimental Farm of the Empresa de Pesquisa Agropecuária de Minas Gerais (EPAMIG), located in Uberaba, Minas Gerais, Brazil.

Sixteen Gyr dairy bulls (Bos taurus indicus), from five high-producing dairy herd farms, and mothers with an average milk production of over $6,000 \mathrm{~kg} / \mathrm{year}$ were initially used. Cattle underwent a high selection pressure for 
reproductive efficiency and early sexual maturing. They were clinic and andrologycally monitored for a period of nine months (April-December 2007), with average ages (months) of $16.3 \pm 1.5$ and $20.1 \pm 1.58$ and weight $(\mathrm{kg})$ of $272.6 \pm 40.5$ and $373.3 \pm 31.6$ at the beginning and end of the experimental period, respectively.

Data were adjusted for age at puberty, according to Brito et al. (2004), in which five periods were determined according to the onset of puberty, from 60 days prior to 60 days after the time zero of puberty $(-60,-30,0,+30$ and +60 days). Under these data adjustments, all variables were compared between periods.

Before the experimental phase, the animals underwent a 30-day adaptation period, in an individual confinement area, receiving a diet containing $20 \%$ crude protein, $70 \%$ total digestible nutrients and $1.105 \mathrm{Mcal} / \mathrm{kg}$ net energy, based on $1 \%$ of body weight, plus corn silage, mineral and water ad libitum. The same diet was kept throughout the whole experimental period.

At the end of the experimental period, according to the Breeding Soundness Evaluation (Vale Filho et al., 2010) and timing of puberty (Wolf et al., 1965), two distinct groups were observed, according to Folhadella et al.(2006): the first ( $\mathrm{n}=8$, considered early maturing, $17 \pm 1.6$ months) characterized by animals that reached puberty before the average puberty age of the breed (18.0 months) and the second group $(\mathrm{n}=8$, considered late maturing, 19.2 \pm 1.5 months) characterized by those animals that reached this pattern after the average age at puberty of the breed.

Semen samples were obtained by electro-ejaculation and were evaluated in phase contrast microscopy, according to CBRA (1998). A semen sample of $1 \mathrm{ml}$ was diluted at a 1:1 ratio in a buffer solution ( $40 \mathrm{~mm}$ Tris base, $2 \mathrm{mM} \mathrm{CaCl}$, $0.01 \%$ sodium azide, Pepstatin A $1 \mu \mathrm{M}$ PMSF $1 \mathrm{mM}$ ) to prevent proteolysis (Bellin et al., 1994) and immediately frozen at $-196^{\circ} \mathrm{C}$ in liquid nitrogen for transportation to the laboratory, where the samples were thawed and centrifuged at $1200 \mathrm{~g}$ for $15 \mathrm{~min}$ at $4{ }^{\circ} \mathrm{C}$ to separate the sperm cells from seminal plasma and other possible contaminants.

A $500-\mu \mathrm{L}$ sample of seminal plasma $(250 \mu \mathrm{L}$ and $250 \mu \mathrm{L}$ of buffer) was initially subjected to a gel filtration column, Superose-12 ${ }^{\circledR}$ (HR 10/30, General Electric Company, Piscataway/USA) in a fast performance liquid chromatography (FPLC) with mobile phase consisting of: Tris $20 \mathrm{mmol}$; $\mathrm{NaCl}$, $50 \mathrm{mmol}, \mathrm{pH} 8$, for the verification of the different fractions or peaks of proteins (Martins, 2010).

To estimate the molecular weights in each peak or distinct protein fraction, the filtration column was calibrated with six different proteins of increasing molecular weight (bovine lung aprotinin: $6.5 \mathrm{kDa}$; Cytochrome $\mathrm{C}$ from horse heart: $12.4 \mathrm{kDa}$; bovine carbonic anhydrase: $29 \mathrm{kDa}$; bovine serum albumin: $66 \mathrm{kDa}$; Alcohol Dehydrogenase: $150 \mathrm{kDa}$; $\beta$-amylase of sweet potato: $200 \mathrm{kDa}$; Blue Dextran: 2,000 kDa Sigma-Aldrich ${ }^{\circledR}$ ). According to the logarithmic regression of the value of the molecular weight of proteins as a function of retention time in the column, the approximate molecular weight of proteins of each peak was calculated, according to the formula: $y=-6.66 \mathrm{x}+3.314 .46 \mathrm{x} 2$, where $\mathrm{x}=\mathrm{y}=\mathrm{Kav}$ $\log$ molecular weight.

Thus, the fractions related to the molecular weights of each hormone (insulin: $5.5 \mathrm{kDa}$; free leptin: $16 \mathrm{kDa}$; bound leptin: $250 \mathrm{kDa}$ ) were separated for posterior analysis. For leptin, the free and bound fractions were grouped into the same tube to go through the same analysis process. After gel filtration, the samples collected at the outlet of the flow of fast protein liquid chromatograpghy (FPLC), representing each peak, were grouped by molecular weight in a single tube to be lyophilized. Next, samples were kept at $-20^{\circ} \mathrm{C}$ until the moment of radiometric analysis.

The leptin and insulin concentrations were determined, respectively, by multi-species ${ }^{\circledR}$ XL-85K (LINCO Research, Missouri / USA) and PI-12K ${ }^{\circledR}$ kit swine (LINCO Research, Missouri/USA) radioimmunoassay kits. Just before analysis, samples of leptin and insulin were resuspended to a final volume of $250 \mu \mathrm{L}$ and 125 , respectively. Following they were processed according to Henricks et al. (1998) and the results expressed, respectively, in $\mathrm{ng}$ and $\mathrm{U} / \mathrm{mL}$, according to counts per minute (COM) obtained in the gamma counter, taking into account the dilution factor of the samples after being resuspended.

It was also tested if animals with higher or lower percentage of major sperm defects have higher or lower values of insulin and leptin in seminal plasma, as the literature suggests that human patients with seminal plasma levels of insulin (Baccetti et al., 2002) and leptin (Aquila et al., 2008) below the physiologic standards have higher amount of sperm cells with major defects. Therefore, after statistical analysis (early and regular puberty), the animals were separated into groups of higher and lower percentage of major defects, according to CBRA (1998), for comparison of insulin and leptin values in the seminal plasma.

After adjusting the data according to age in relation to puberty (days) at time 0 (zero) a frequency distribution of the ages of the 16 animals was carried out using the FREQ procedure of SAS (Statistical Analysis System, version 9.1.3). As a point of separation of the groups the median, 18 months of age at the time was adopted.

Thus, animals with age at puberty below the median were considered early, and those above the median were considered regular. The values of insulin and leptin were 
tested for normality using Shapiro-Wilk, KolmogorovSmirnov and asymmetry and kurtosis, for the UNIVARIATE procedure with options NORMAL and PLOT, using the SAS statistical package SAS (Statistical Analysis Sytem, 2002). The variable insulin was logarithmically transformed $[\log (\mathrm{x}+1)]$ to fit the normality curve (Sampaio, 2002).

The design was of randomized blocks in subplots with 8 repetitions. The animal group was considered main plot and collection time $(-60,-30,0,+30$ and +60$)$, the subplots. Analyses were performed using the MIXED procedure of SAS statistical package. The group effect was evaluated by the $F$ test and the age effects were estimated by adjustment of linear and quadratic regression models.

Comparisons between ages within each group were performed by SNK tests using the GLM procedure of SAS. The regression models of the variables in relation to age at puberty were adjusted using the PROC REG feature of SAS. When the interaction between group and age was significant, a regression model for each group was fitted.

Correlations between parametric variables were estimated by Pearson correlation coefficient using the PROC CORR and the associations between the parametric and the nonparametric variables by the Spearman correlation coefficient, using the PROC CORR with the SPEARMAN option of SAS (SAS, 2002). Results showing no statistical difference between groups and between sampling periods were pooled for joint analysis.

\section{Results and Discussion}

Insulin concentration in seminal plasma of early animals were of $36.04 \pm 21.45 ; 42.75 \pm 31.09 ; 26.55 \pm 11.90 ; 42.31 \pm 34.42$ and $28.28 \pm 12.38 \mu \mathrm{U} / \mathrm{mL}$ for times $-60,-30,0,30$ and 60 of puberty, respectively. For animals of regular puberty, these values were, respectively, $34.16 \pm 12.34,30.45 \pm 20.47$, $38.99 \pm 27.90,32.14 \pm 22.13$ and $36.19 \pm 1.17 \mu \mathrm{U} / \mathrm{mL}$, with no statistical differences $(\mathrm{P}>0.05)$ between the stages of sexual development ( -60 to +60$)$ or between groups (early and

Table 1 - Insulin concentration in seminal plasma along the sexual development

\begin{tabular}{lc}
\hline $\begin{array}{l}\text { Stages of sexual } \\
\text { development (days) }\end{array}$ & $\begin{array}{c}\text { Insulin concentration } \\
(\mu \mathrm{U} / \mathrm{mL})\end{array}$ \\
\hline-60 & $35.15 \pm 16.93$ \\
-30 & $36.60 \pm 26.21$ \\
0 & $26.82 \pm 09.81$ \\
30 & $43.56 \pm 31.71$ \\
60 & $32.24 \pm 16.71$ \\
\hline
\end{tabular}

$\mathrm{P}<0.05$ by $\mathrm{F}$ test. regular puberty, $\mathrm{P}>0.05)$, being then grouped together for joint analysis (Table 1).

No reports on the insulin concentration in bovine seminal plasma were found, enabling no comparison with the results registered here. However, similar value was found by Póvoa Júnior et al. (1973) in normospermic men (45.8 $\pm 15.1 \mu \mathrm{U} / \mathrm{mL})$. Also, Hicks et al (1973), working with non-diabetic men found lower seminal plasma concentrations than those reported by Póvoa Júnior et al. (1973) or in the present study, with values of $19 \pm 3 \mu \mathrm{U} / \mathrm{mL}$, representing more than twice the values for human serum concentration

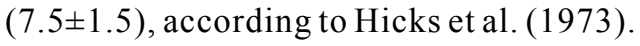

In cattle, higher concentration is also found when compared with the seminal plasma serum concentration of this hormone $34.56 \pm 22.01 \mathrm{U} / \mathrm{mL}$ (data from this study) and $10.9 \pm 1.0 \mathrm{U} / \mathrm{mL}$, reported by Delavaud et al. (2002).

It was reported that insulin promotes the differentiation of spermatogonia into primary spermatocytes by binding to the IGF-I receptors, once both, plasma and acrossomal membranes represent cytological targets for this hormone (Nakayama et al., 1999).

In addition, insulin is also essential for the glucose movement across the plasmatic membrane, increasing the number of specific transport proteins (Stabenfeldt \& Davidson, 2003), and so sperm motility.

Insulin concentrations in seminal plasma showed no correlation with any of those characteristics (Table 2). Similar results were reported by García-Díez et al. (1991), who, working with two groups of men, normoglycemic and diabetic, found higher insulin concentration in seminal plasma, compared with insulin serum concentration in all groups studied, but with no correlation between these values and sperm parameters.

However, Baccetti et al. (2002), working with diabetic men, demonstrated by transmission electron microscopy, that the sperm cells of this group showed severe ultrastructural defects in sperm cells compared with the control group (normoglycemia). They also reported the possibility of the reproductive impairment recognized in men with diabetes mellitus being a result of interference from the disease on the hypothalamic-pituitary-gonadal axis at multiple levels, as indicated by the characteristics of abnormal sperm cells in the ejaculate.

Thus, as there was no significant difference $(\mathrm{P}>0.05)$ between animal groups and between periods of sexual development, the animals were separated by concentration of major defects ( $11>20 \%$ and $\mathrm{G} 2<20 \%$ ). There was difference $(\mathrm{P}<0.05)$ in seminal plasma insulin concentration between groups of animals with low $(40.01 \pm 25.37 \mu \mathrm{U} / \mathrm{mL})$ 
Table 2 - Pearson and Spearman correlations between insulin concentration in seminal plasma and andrologycal characteristics of Gyr dairy bulls at peripuberty

\begin{tabular}{lccccccccccc}
\hline & Age & Weight & SC & Volume & Conc & MD & mD & TD & Nor & Mot* & Vig* \\
\hline Insulin & 0.11 & -0.15 & -0.15 & -0.09 & -0.004 & -0.19 & 0.07 & -0.17 & 0.17 & 0.09 & 0.07 \\
$\mathrm{P}$ & 0.32 & 0.19 & 0.19 & 0.42 & 0.97 & 0.11 & 0.58 & 0.17 & 0.17 & 0.44 & 0.53 \\
\hline
\end{tabular}

SC - scrotal circumference; Conc - spermatic concentration; MD - major defects; mD - minor defects; TD - total defects; Nor: normal; Mot - spermatic motility; Vig - spermatic vigor. *Spearman correlations.

and those with high percentage of major sperm defect $(31.08 \pm 18.58 \mu \mathrm{U} / \mathrm{mL})$.

Although the methodology used could not identify ultra-structures, the data registered corroborate those reported by Baccetti et al. (2002), allowing the speculation on the importance of this hormone in the structural condition of the sperm cell, also serving as a reference for determining the values of this hormone in bovine seminal plasma.

Seminal plasma leptin concentration did not differ ( $P>0.05)$ between the stages of sexual development ( -60 to $+60)$ or between animals of early and regular puberty $(\mathrm{P}>0.05)$. Early animals showed leptin values of $26.39 \pm 13.11$, $24.69 \pm 10.73,21.25 \pm 8.82,24.07 \pm 9.43$ and $21.31 \pm 4.96 \mathrm{ng} / \mathrm{mL}$, respectively, for moments $-60,-30,0,30$ and 60 of puberty (Figure 1). Animals of regular puberty showed leptin values of $20.01 \pm 6.19,24.02 \pm 8.64,27.01 \pm 8.46,23.54 \pm 9.30$ and $28.68 \pm 14.96 \mathrm{ng} / \mathrm{mL}$ for these same moments, respectively *.

Early animals showed greater seminal plasma leptin concentration at times $-60,-30$ and +30 . In the other moments $(0$ and +60$)$, animals of regular puberty showed higher seminal plasma leptin concentrations, even though with no difference from early animals $(\mathrm{P}>0.05)$.

Since there was no difference $(\mathrm{P}>0.05)$ between regular and early puberty groups and between stages of sexual development ( -60 to +60$)$ within groups, the data were grouped showing values of $23.19 \pm 10 ; 43,24.35 \pm 09.4$; $22.41 \pm 09.90 ; 23.76 \pm 09.69$ and $24.99 \pm 11.42$ for times $-60,-30$, 0,30 and 60 , respectively.

No reports on measurements of seminal plasma leptin concentration of cattle were found; notwithstanding, Nikbakh et al. (2010) registered leptin mRNA receptors in bull sperm cells, indicating that the presence of such receptors in these cells point to a physiological role of this hormone, as has been found in humans and pigs (Aquila et al. 2005; Aquila et al., 2008).

Lackey et al. (2002), working with humans and pigs registered leptin seminal plasma concentrations of, respectively, $0.86 \pm 0.04$ and $10.88 \pm 0.84 \mathrm{ng} / \mathrm{mL}$, which are lower than those observed in the animals of the present study $(23.76 \pm 09.97 \mathrm{ng} / \mathrm{mL})$.

Von Sobbe et al. (2003), working with humans, determined correlation between seminal and serum leptin concentrations. Even though no study on this matter was found in cattle, it can also be expected that animals with higher serum leptin also have a higher concentration of this hormone in the seminal plasma. However, when analyzing bovine data on serum leptin, results of low concentrations are found, as those from Sansinanea et al. (2001) with Holstein steers (average concentration of $6.05 \pm 0.19 \mathrm{ng} / \mathrm{mL}$ ), not consistent with those found in the present study.

Part of the results registered in the present study may be explained by the type of kit used for the determination of this hormone. According to Delavaud et al. (2002), when using multi-species (from sheep in cattle) kit for determination of leptin serum concentrations, one can expect results at least $50 \%$ below the real ones, with values of $2.4 \pm 0.2 \mathrm{ng} / \mathrm{mL}$ and $5.9 \pm 0.4 \mathrm{ng} / \mathrm{mL}$, respectively.

However, since no results on measurements of this hormone in seminal plasma of cattle were found, no comparison between serum and seminal plasma was done, which did not enable for inferences whether the highest concentration of leptin registered in the present study,

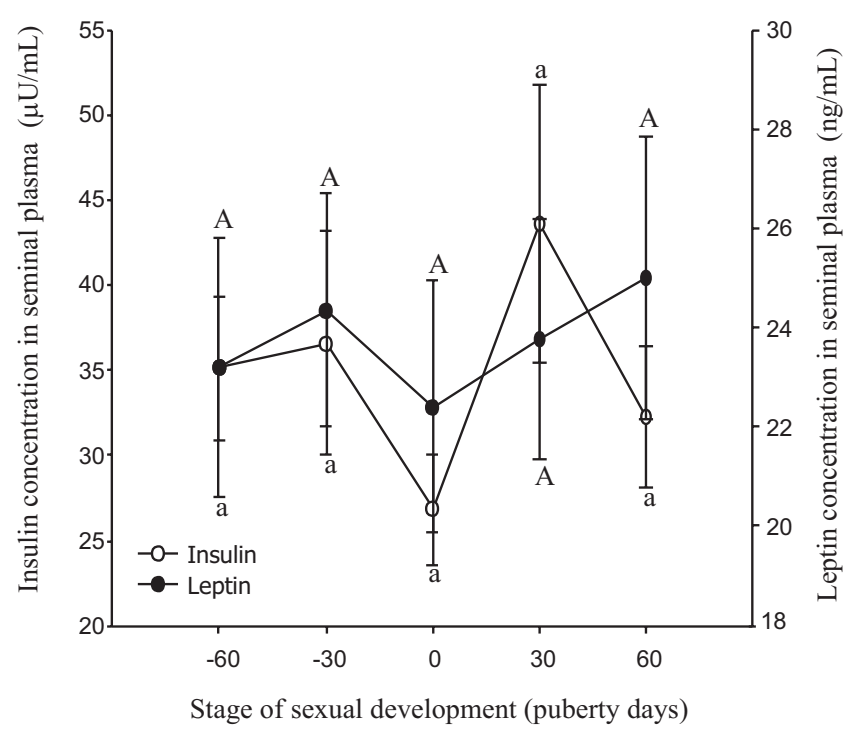

Figure 1 - Seminal plasma leptin and insulin concentrations in Gyr dairy bulls during the peripuberty (mean \pm standard error). ( $\mathrm{P}>0.05$ within the same treatment by SNK test). 
when compared with concentrations in humans and pigs, is because of the animals under study or the methodology applied.

Although there was no difference between the stages of development, some modulation of leptin concentration was observed within the period $(-60$ to +60$)$, which was initially accompanied by the insulin concentrations.

According to Patel et al. (1998), insulin has a dependency on leptin. These authors remarked that the lack of insulin inhibits the synthesis of leptin, as evidenced by the low concentration of leptin in streptozotocin-induced diabetic rats, while insulin replacement resulted in restoration of the leptin level. However, insulin levels showed correlation of low magnitude $(r=0.21)$ with the concentration of leptin in seminal plasma at a significance level of $6 \%$, confirming the modulation of these hormones within the stages of sexual development (Figure 1), suggesting, according to the study of Patel et al. (1998), a possible effect of these hormones on each other.

\section{Conclusions}

Although the seminal insulin concentration does not differ between groups or between ages within groups, it is connected to the structural quality of the sperm cell, serving as a complementary parameter for evaluating future breeders. Different values of seminal leptin concentrations are not correlated with any of the sperm parameters.

\section{References}

ANDÒ, S.; AQUILA, S. Arguments raised by the recent discovery that insulin and leptin are expressed in and secreted by human ejaculated spermatozoa. Molecular and Cellular Endocrinology, v.245, n.1-2, p.1-6, 2005.

AQUILA, S.; GENTILE, M.; MIDDEA, E. et al. Autocrine regulation of insulin secretion in human ejaculated. Spermatozoa. Endocrinology, v.146, n.2, p.552-557, 2005.

AQUILA, S.; RAGO, V.; GUIDO, C. et al. Leptin and leptin receptor in pig spermatozoa: evidence of their involvement in sperm capacitation and survival. Reproduction, v.136, n.1, p.23-32, 2008.

BACCETTI, B.; la MARCA, A.; PIOMBONI, P. et al. Insulindependent diabetes in men is associated with hypothalamopituitary derangement and with impairment in semen quality. Human of Reproduction, v.17, n.10, p.2673-2677, 2002.

BELLIN, M.E.; HAWKINS, H.E.; AX, R.L. Fertility of range beef bulls grouped according to presence or absence of Heparinbinding proteins in sperm membranes and seminal fluid. Journal of Animal Science, v.72, p.2441-2448, 1994.

BRITO, L.F.C.; SILVA, A.E.D.F.; UNANIAN, M.M. et al. Sexual development in early- and late-maturing Bos indicus and Bos indicus $\times$ Bos taurus crossbred bulls in Brazil. Theriogenology, v.62, n.7, p.1198-1217, 2004

CALVETE, J.J.; MANN, K.; SANZ, L. et al. The Primary structure of BSP-30K, a major lipid-, gelatin-, and heparin-binding glycoprotein of bovine seminal plasma. FEBS Letters, v.399, n.1-2, p.147-152, 1996.

COLÉGIO BRASILEIRO DE REPRODUÇÃO ANIMAL - CBRA Manual para exame andrológico e avaliação de sêmen animal. 2.ed. Belo Horizonte: 1998. 49p.

DELAVAUD, C.; FERLAY, A.; FAULCONNIER, Y. et al. Plasma leptin concentration in adult cattle: Effects of breed, adiposity, feeding level, and meal intake. Journal of Animal Science, v.80, n.5, p.1317-1328, 2002.

FOLHADELLA, I.M.; SÁ, W.F.; FERREIRA, A.M. et al. Características andrológicas de touros da raça Gir. Arquivo Brasileiro de Medicina Veterinária e Zootecnia, v.58, n.5, p.809-815, 2006.

GARCÍA-DÍEZ, L.C.; CORRALES-HERNANDEZ, J.J.; HERNANDEZDIAZ, J. et al. Semen characteristics and diabetes mellitus: significance of insulin in male infertility. Archive of Andrology, v.26, n.2, p.119-128, 1991. (Abstract)

GLANDER, H.-J.; LAMMERT, A.; PAASCH, U. et al Leptin exists in tubuli seminiferi and in seminal plasma. Andrology, v.34, n.4, p.227-233, 2002.

HENRICKS, D.M.; KOUBA, A.J.; LACKEY, B.R. et al. Identification of insulin-like growth factor $\mathrm{i}$ in bovine seminal plasma and its receptor on spermatozoa: influence on sperm motility. Biology of Reproduction, v.59, n.2, p.330-337, 1998.

HICKS, J.J.; ROJAS, L.; ROSADO, A. Insulin regulation of spermatozoa metabolism. Endocrinology, v.92, n.3, p.833-839, 1973.

JORSARAEI, S.G.A.; HIROAKI-SHIBAHARA, H.; AYUSTAWATI et al. The in-vitro effects of nicotine, cotinine and leptin on sperm parameters analyzed by CASA system. Iranian Journal of Reproductive Medicine, v.6, n.3, p.157-165, 2008.

LACKEY, B.R.; GRAY, S.L.; HENRICKS, D.M. Measurement of leptin and insulin-like growth factor-I in seminal plasma from different species. Physiological Research, v.51, n.3, p.309-311, 2002.

MANJUNATH, P.; CHANDONNET, L.; LEBLOND, E. et al. Major proteins of bovine seminal vesicle bind to spermatozoa. Biology of Reproduction, v.50, n.1, p.27-37, 1993.

MARTINS, J.A.M. Desenvolvimento reprodutivo e análise das proteínas do plasma seminal com afinidade à heparina, em tourinhos Gir selecionados para a produção de leite. 2010 71f. Tese (Doutorado) - Universidade Federal de Minas Gerais, Belo Horizonte.

NAKAYAMA, Y.; YAMAMOTO, T.; ABE, S.I. IGF-I, IGF-II and insulin promote differentiation of spermatogonia to primary spermatocytes in organ culture of newt testes. International of Journal Developmental Biology, v.43, n.4, p.343-347, 1999.

NIKBAKH, G.; MEHR, M.R.A.; BAGHBANZADEH, A. et al. Leptin receptor $m R N A$ in bull ejaculated spermatozoa. Reproduction of Domestic Animal, v.45, n.2, p.237-242, 2010.

PATEL, B.K.; KOENIG, J.I.; KAPLAN, L.M. et al. Increase in plasma leptin and Lep mRNA concentrations by food intake is dependent on insulin. Metabolism, v.47, n.5, p.603-607, 1998

PÓVOA JÚNIOR, H.; REZENDE, M.T.L.; SOUZA, A.C. et al. Insulina imunoreativa em líquidos biológicos. Memórias do Instituto Oswaldo Cruz, v.71, n.4, p.425-438, 1973.

SAMPAIO, I.B.M. Estatística aplicada à experimentação animal. 2.ed. Belo Horizonte: FEP MVZ Editora, 2002. 265p.

SANSINANEA, A.S.; CERONE, S.I.; ZONCO, I. et al. Serum leptin levels in cattle with different nutritional conditions. Nutrition Research, v.21, n.7, p.1045-1052, 2001.

SHRIVASTAV, P.; SWANN, J.; JEREMY, J.Y. et al. Sperm function and structure and seminal plasma prostanoid concentrations in men with IDDM. Diabetes Care, v.12, n.10, p.742-744, 1989

SILVESTRONI, L.; MODESTI, A.; SARTORI, C. Insulin-sperm interaction: effects on plasma membrane and binding to acrosome. Archives of Andrology, v.28, n.3, p.201-211, 1992 
STABENFELDT, G.H.; DAVIDSON, A.P. Reproducción y lactación. In: CUNNINGHAM, D.V.M. (Ed.) Fisiología veterinaria, 3.ed. Saunders: Madrid, 2003. p.374-429.

VALE FILHO, V.R.; ANDRADE, V.J.; AZEVEDO, N.A. Avaliação andrológica e seleção de tourinhos zebu para reprodução. In: SIMPÓSIO DE PRODUÇ̃̃O DE GADO DE CORTE, 7.; SIMPÓSIO INTERNACIONAL DE PRODUÇÃO DE GADO DE CORTE, 3., 2010, Viçosa, MG. Anais.... Viçosa, MG, 2010. p.363-400.
VON SOBBE, H.-U.; KOEBNICK, C.; JENNE, L. et al. Leptin concentrations in semen are correlated with serum leptin and elevated in hypergonadotrophic hypogonadism. Andrologia, v.35, n.4, p.233-237, 2003

WOLF, F.R.; ALMQUIST, J.O.; HALE, E.B. Prepubertal behavior and puberal characteristics of beef bulls on high nutrient allowance. Journal Animal Science, v.24, n.3, p.761-765, 1965. 